RASĀYAN J. Chem.

Vol. 13 | No. 1 |628 - 635| January - March | 2020 ISSN: 0974-1496 | e-ISSN: 0976-0083 | CODEN: RJCABP

\title{
ENHANCEMENT OF ANTIBACTERIAL ACTIVITY OF SUEDE LEATHER THROUGH COATING SILVER NANOPARTICLES SYNTHESIZED USING PIPER BETLE
}

\author{
E. Rohaeti ${ }^{1, *}$, E. Kasmudjiastuti ${ }^{2}$, R. S. Murti ${ }^{2}$, and D. Irwanto ${ }^{2}$ \\ ${ }^{1}$ Department of Chemistry Education, Faculty of Mathematics and Natural Sciences, \\ Universitas Negeri Yogyakarta, 55281, Indonesia \\ ${ }^{2}$ Center for Leather, Rubber and Plastic, 55166, Indonesia \\ *E-mail: eli_rohaeti@uny.ac.id
}

\begin{abstract}
The objective of this study was to modify suede leather by coating Ag nanoparticles which synthesized with an extract from green betel leaf. The success of suede leather modification with silver nanoparticles was analyzed by FTIR spectrophotometer, SEM tool, and antibacterial activity test. Characteristic of Ag nanoparticles was analyzed through using a UV-Vis spectrophotometer. The stages of experimental research carried out where the extraction of betel leaves, preparation of $\mathrm{Ag}$ nanoparticles with betel leaf extract using precursors of silver nitrate solution, characterization of Ag nanoparticles with Ultra Violet-Visible spectrophotometer, modification of suede leather with silver nanoparticles, characterization of suede leather without modification with FTIR spectrophotometer, SEM observations, and antibacterial activity tests with diffusion techniques. The results showed that betel leaf extract could change silver nitrate salt to Ag nanoparticles as indicated by UV-Vis' absorption which peaked at $259 \mathrm{~nm}$ and $456 \mathrm{~nm}$. The FTIR spectrum showed that silver nanoparticles were successfully introduced into suede leather with the interaction between $-\mathrm{OH}$ free and $-\mathrm{C}=\mathrm{O}$ free with $\mathrm{Ag}$ nanoparticles. SEM photos showed that Ag nanoparticles successfully layered the surface of suede leather tissue and the shape of the silver nanoparticles was spherical. Suede leather with the addition of silver nanoparticles had the best ability to cause the death of $E$. coli bacteria, outperforming leather without modification by 1.8 times and silver nanoparticles in incubation for 36 hours by 1.3 times. The incubation time significantly affected the inhibition in the growth of $S$. aureus bacteria by suede leather samples.
\end{abstract}

Keywords: Antibacterial Activity, Piper Betle, Suede Leather, Silver Nanoparticle, SEM.

(C) RASĀYAN. All rights reserved

\section{INTRODUCTION}

Nanotechnology is the science and engineering of the creation of material and functional structures on a nanometer scale. ${ }^{1,2}$ One of the most popular developments in nanotechnology is the synthesis of silver nanoparticles. The silver nanoparticle is a new anti-microbial agent to the growth of miicroorganisms ${ }^{3}$. Silver nanoparticles as antimicrobials are used in various industrial fields such as electronics, medicine, optics, cosmetics, textiles ${ }^{2,4,5}$ and leather. ${ }^{3,6}$ Many ways to synthesize nanoparticles are through physical, chemical and biological methods. One of them is to reduce silver ions using plant extracts. ${ }^{7,9}$ The nanomaterial synthesis is biologically called biosynthetic. Biosynthetic nanoparticles involve compounds from plants such as flavonoids. ${ }^{8}$ Flavonoids can change salts to nanoparticles. This is caused by the functional groups in flavonoids. Flavonoids are a large group of polyphenol compounds that have groups classes: anthocyanins, isoflavonoids, flavonols, and flavones. Flavonoids contain several functional groups that play a role in the formation of nanoparticles. There is a postulate that tautomeric transformation from flavonoids from enol to keto forms can release reactive hydrogen atoms which can reduce metal ions to nanoparticles. Some types of plants contain antioxidant compounds such as phenolics, terpenoids, flavonoids and tannins. Banana peel extract could be used as an agent in producing nanoparticles. ${ }^{10}$ Phenolic compounds have the characteristic of having at least one aromatic ring (C6) with

Rasayan J. Chem., 13(1), 628-635(2020)

http://dx.doi.org/10.31788/RJC.2020.1315516

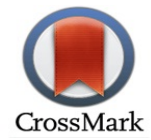




\section{RASĀYAN J. Chem.}

Vol. 13 | No. 1 |628 - 635| January - March | 2020

one or more hydroxyl groups. Phenolic compounds have antioxidant properties because they have a strong tendency to reduce metals. Phenolic compounds' ability to reduce metals exists because they have high nucleophilic characters from aromatic rings. ${ }^{11}$

This decade, researchers are finding alternative ways for the development of cost-effective procedures, high reproducibility, stable procedures, and metal nanoparticles produced using resource-based materials ${ }^{2}$.

Green betel leaves (Piper betle) contain phenols, tannins, sterols, flavonoids, and antioxidant compounds in large quantities. ${ }^{9,12}$ This study synthesizes silver nanoparticles using betel leaf extract as a bioreductor and adding of PVA to prevent agglomeration of the Ag nanoparticles produced. Previous researches have revealed the use of sodium citrate in producing nanoparticles ${ }^{13}$ and the use of betel leaf extract in the preparation of silver nanoparticles. ${ }^{14,15}$ The silver nanoparticles and the gold nanoparticles have successfully produced by green synthesis using pine gum. ${ }^{16}$ However, in those studies, did not add any stabilizers in the synthesis process of nanoparticles. In our research, the addition of stabilizers in the form of PVA in producing nanoparticles has been tried. This research was carried out because it had never been applied to suede leather before. The cotton fabric and leather products showed excellent antibacterial activity against Brevibacterium linens. ${ }^{14}$ The study aimed to determine the effectiveness of silver nanoparticles with bioreductors from betel leaf extract as anti-bacterial on suede leather.

\section{EXPERIMENTAL}

\section{Materials}

The suede leather was purchased from the leather industry in Yogyakarta, Indonesia. Salt of silver nitrate, PVA liquid, $\mathrm{C}_{2} \mathrm{H}_{5} \mathrm{OH}, \mathrm{C}_{3} \mathrm{H}_{6} \mathrm{O}$, and hexadecyltrimethoxysilane was purchased as commercial products ${ }^{5}$. Nutrient Agar (NA) and Nutrient Broth (NB) were purchase from Oxoid. Staphylococcus aureus ATCC 25923 and Escherichia coli 32518 were obtained from the collection of Faculty of Medicine, Gadjah Mada University Yogyakarta, Indonesia ${ }^{5}$. The study was conducted in consecutive stages as follows: extraction of piper betle leaf, preparation of silver nanoparticle, deposition of silver nanoparticles on suede leather, characterization using UV-Vis, FTIR, SEM, and antibacterial activity testing.

\section{Methods \\ Preparation of Silver Nanoparticle (Ag)}

As much as $100 \mathrm{~mL}$ distilled water was put into a glass beaker that has a volume of $500 \mathrm{~mL}$ to wash 20 grams of green betel leaves. Then the boiling process was carried out for 20 minutes to obtain an extract of green betel leaf. This extract was then filtered using Whatman no. 42 at room temperature. To about 1 $\mathrm{mL}$ of extract, $40 \mathrm{~mL}$ of silver nitrate solution $1.10^{-3} \mathrm{M}$ was added. The mixture was left for about 2 hours to react and then $12 \mathrm{~mL}$ of $1 \%$ PVA solution was added while stirring for another 2 hours. Then, the solution was left for 4 days to produce colloidal silver nanoparticles. The colloid was then analyzed by using a spectrophotometer of Ultra Violet-Visible.

\section{Deposition of Ag Nanoparticles on Leather Fiber (Leather + Ag/S1)}

The suede leather was prepared so that it was $5 \mathrm{~cm}$ x $5 \mathrm{~cm}$ in size, then was washed with acetone for 30 minutes and rinsed thoroughly in non-ion distilled water for about 30 minutes and finally dried using a hairdryer. After, the suede leather was soaked in silver nanoparticles colloid, rotated using a shaker at 153 rpm for 24 hours and left to dry at room temperature.

\section{Test of Antibacterial Activity}

The capability of suede leather in inhibiting the growth of bacteria was analyzed by measuring of inhibition zone. The diffusion method was conducted in determining the antibacterial activity of suede leather. The bacteria growth was prepared in media such as NA and NB. As much as 14 gram of NA was dissolved in $500 \mathrm{~mL}$ of distilled water and 1.3 gram of NB in $250 \mathrm{~mL}$ of distilled water. Each sample of suede leather was prepared with a diameter of $6 \mathrm{~mm}$, then put in the petri dish and left to stand in an oven with a temperature of $25^{\circ} \mathrm{C}$ for 24 hours. The sample was then observed in an inhibition zone for up to 72 
RASĀYAN J. Chem.

Vol. 13 | No. 1 |628 - 635| January - March | 2020

hours. Data of measurement of clear zone diameter on leather against Staphylococcus aureus and Escherichia coli were analyzed by statistic test using IBM SPSS Statistics $25 .^{10}$

\section{Analysis of UV-Vis}

The analysis of UV-Vis was conducted to study the success of the formation of Ag nanoparticles by green synthesis using betel leaf extract. The change in absorption peak at certain wavelengths showed the success of silver nanoparticles formation. ${ }^{5,10,14}$

\section{Analysis of FTIR}

The analysis using an FTIR spectrophotometer was conducted to analyze the functional groups of leather before and after the modification with Ag nanoparticles synthesized with piper betle leaf extract.

\section{Observation of Morphology by using SEM}

SEM analysis was done to observe the image of $\mathrm{Ag}$ nanoparticles in the matrix of leather suede. Observations were carried out at 2000 times and 5000 times magnification, respectively.

\section{RESULTS AND DISCUSSION}

\section{The Success of Forming Silver Nanoparticles using Betel Leaf Extract}

The silver nitrate solution shows maximum absorbance at $61 \mathrm{~nm}$ whereas silver nanoparticle colloids show maximum absorbance at $259 \mathrm{~nm}$ and $456 \mathrm{~nm}$ (Fig.-1). The presence of two new absorption peaks in the UV-Vis spectrum of silver nanoparticle colloids shows the success of betel leaf extract in converting silver ions to silver nanoparticles. The functional groups $-\mathrm{OH}$ of flavonoids in leaf extract can reduce silver ions. ${ }^{17}$ Functional groups of tannin components manipulate actively in changing $\mathrm{Ag}^{+}$to $\mathrm{Ag}^{0}$ in colloidal formation. ${ }^{18}$ Flavonoids and tannins are large compounds in betel leaf. ${ }^{19,20}$

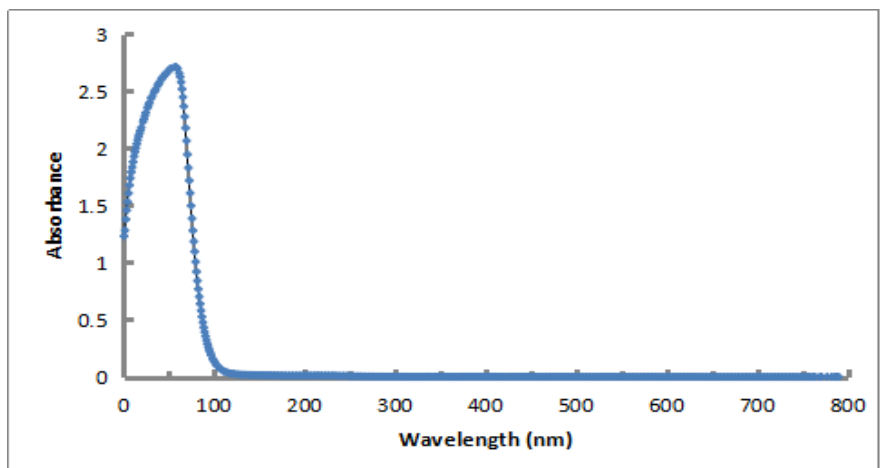

(a)

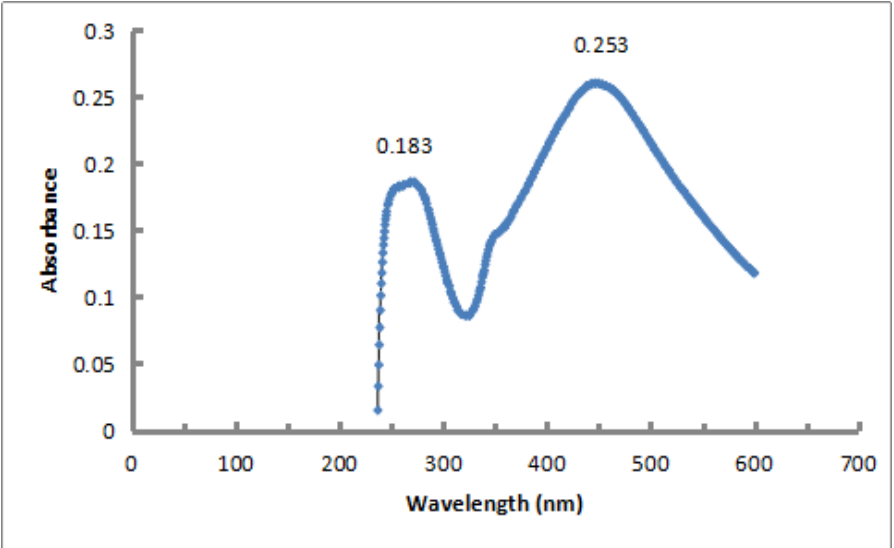

(b)

Fig.-1: The Spectrum of UV-Vis of Nitrate Solution (a) and Silver Nanoparticle (b)

630 
RASĀYAN J. Chem.

Vol. 13 | No. 1 |628 - 635| January - March | 2020

The Difference of Antibacterial Activity on The Suede Leather in Preventing the Life of Staphylococcus aureus and Escherichia coli

Table-1 shows that the three types of samples, namely silver nanoparticle, leather, and leather + nanoAg all have significance below 0.05 . This means that the three samples have significantly different abilities to prevent the life of both Staphylococcus aureus and Escherichia coli bacteria. The difference in inhibition zone between 2 types of samples can be seen in Table- 2 .

Table-1: ANOVA Test: The Effect of Type of Sample and Incubation Time on The Inhibition Ability toward $S$. aureus and E. coli

\begin{tabular}{l|l|l|l|l|l}
\hline \multicolumn{7}{l}{ Staphylococcus aureus } \\
\hline Source of data & Sum & Df & Average & F & Sig. \\
\hline Corrected model & 2.277 & 2 & 1.138 & 16.559 & 0.000 \\
\hline Intercept & 44.743 & 1 & 44.743 & 650.825 & 0.000 \\
\hline VAR00001 & 2.277 & 2 & 1.138 & 16.559 & 0.000 \\
\hline \multicolumn{7}{l}{ Escherichia coli } \\
\hline Source of data & Sum & Df & Average & F & Sig. \\
\hline Corrected model & 10.318 & 2 & 5.159 & 96.259 & 0.000 \\
\hline Intercept & 51.040 & 1 & 50.040 & 952.343 & 0.000 \\
\hline VAR00001 & 10.318 & 2 & 5.159 & 96.259 & 0.000 \\
\hline
\end{tabular}

Table-2: Interpretation of The Result of LSD Test Between Product Types against Staphylococcus aureus and Escherichia coli

\begin{tabular}{c|c|c}
\hline \multirow{2}{*}{$\begin{array}{c}\text { Type of } \\
\text { Product }\end{array}$} & \multicolumn{2}{|c}{ Conclusion } \\
\cline { 2 - 3 } $\mathrm{Ag}-\mathrm{S} 0$ & Significant & E.coli \\
\hline $\mathrm{Ag}-\mathrm{S} 1$ & Not significant & Significant \\
\hline $\mathrm{S} 0-\mathrm{Ag}$ & Significant & Significant \\
\hline $\mathrm{S} 0-\mathrm{S} 1$ & Significant & Significant \\
\hline $\mathrm{S} 1-\mathrm{Ag}$ & Not significant & Significant \\
\hline $\mathrm{S} 1-\mathrm{S} 0$ & Significant & Significant \\
\hline
\end{tabular}

Table-2 shows that between the silver nanoparticle sample and suede leather after modification with silver nanoparticle samples showed that the inhibiting ability was significantly different against the two types of bacteria. Between the two types of samples, the silver nanoparticle sample and suede leather after modification with silver nanoparticles had the same ability to inhibit $S$. aureus bacteria and while the inhibiting ability was significantly different against $E$. coli. In other words, gram-negative bacteria and gram-positive bacteria can be inhibited by silver nanoparticles and suede leather after modification with the silver nanoparticle. However, suede leather after modification with silver nanoparticles has higher antibacterial activity toward $E$. coli than toward $S$. aureus. This can be caused by gram-negative bacteria having an outer cell wall consisting of lipopolysaccharide and thin cell walls. The functional groups - $\mathrm{NH}$ and $-\mathrm{C}=\mathrm{O}$ bound to the silver in modified leather structure will interact with the chemical functional group on the membrane via covalent bonds to produce clusters that inhibit cell respiration ${ }^{21}$.

Thus, the use of extracts from green betel leaf is effectively embroiled in antibacterial activity and is also used in the production of silver nanoparticles. This is reinforced by data that organic molecules such as terpenoids, alcohols, ketones, aldehydes and carboxylic acids around the nanoparticles. ${ }^{15}$

\section{The Effect of Incubation Time on Antibacterial Activity of Leather toward Staphylococcus aureus} and Escherichia coli

Based on Fig.-2(a) and 2(b), it can be concluded that at increased incubation times, the antibacterial activity of silver nanoparticles, suede leather, and suede leather after modification with silver nanoparticles shows a fluctuating value. Leather without modification showed the highest inhibition zone compared to the leather after modification with silver nanoparticles and silver nanoparticles in preventing the life of $S$. aureus bacteria. This can be caused by the existing composition of various types of proteins 
RASĀYAN J. Chem.

Vol. 13 | No. 1 |628 - 635| January - March | 2020

with functional groups $-\mathrm{NH}$ and $-\mathrm{COO}$ in leather. The existence of these functional groups can interact with the chemical compounds that make up the wall of the membrane cell of the $S$. aureus bacteria, resulting in the lysis and bacterial cell death. ${ }^{20}$. However, all three samples show antibacterial activity against $S$. aureus. Fig.-2(b) shows different results in which leather after modification with silver nanoparticles has the best ability to inhibit $E$. coli bacteria. This can be caused by the interaction of Ag nanoparticles with the wall of the membrane cell of $E$. coli bacteria. The resulting interaction can cause $E$. coli bacterial cell death. The results of the statistical analysis as shown in Table-3 reinforce the results of the graph.

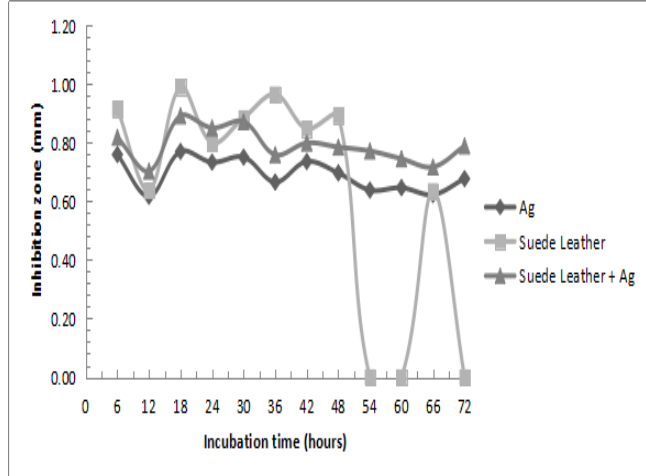

(a)

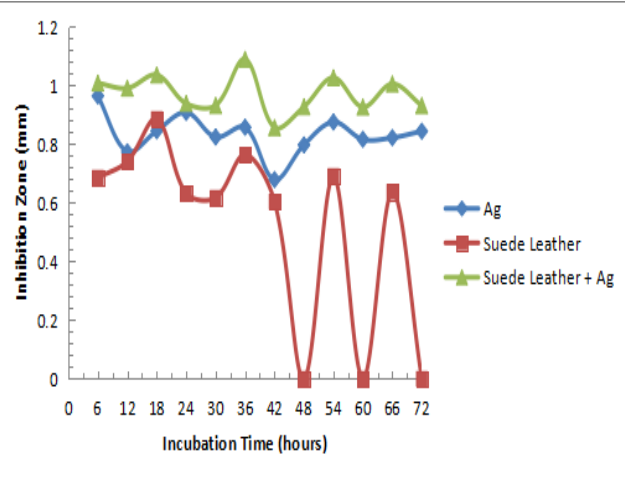

(b)

Fig.-2: The Inhibition Zone of Ag Nanoparticles, Leather, and Leather + Ag Nanoparticles against S. aureus (a) and E. $\operatorname{coli}(\mathrm{b})$

Table-3: Effect of Incubation Time on Differences in Suede Leather Inhibition Zone against S. aureus and E. coli

\begin{tabular}{|c|c|c|}
\hline Type of Sample & Value of Significance & Conclusion \\
\hline \multicolumn{3}{|c|}{ S. aureus } \\
\hline $\mathrm{Ag}$ & 0.020 & Difference \\
\hline S0 & 0.044 & Difference \\
\hline S1 & 0.001 & Difference \\
\hline \multicolumn{3}{|c|}{ E. coli } \\
\hline $\mathrm{Ag}$ & 0.868 & No difference \\
\hline S0 & 0.455 & No difference \\
\hline S1 & 0.487 & No difference \\
\hline
\end{tabular}

\section{The Functional Group of Leather}

The functional groups of leather with and without the addition of silver nanoparticles were determined by using the FTIR spectrophotometer. Characterization of functional groups on leather before and after modification with silver nanoparticles from a solution of silver nitrate salt using a reducing agent of betel leaf extract to study deposit process of nanoparticle on suede leather.

Fig.-3(a) and 3(b) show the FTIR spectrum of leather and leather with addition silver nanoparticles. There appears to be a shift in wavenumbers in the FTIR spectrum of the leather with and without the addition of $\mathrm{Ag}$ nanoparticles. The leather without the addition of $\mathrm{Ag}$ nanoparticles shows the absorption of $-\mathrm{OH}$ group at $\lambda 3294.41 \mathrm{~cm}^{-1}$ with a broad and strong band. Absorption of the aliphatic $\mathrm{C}-\mathrm{H}$ group at $\lambda 2923.78$ $\mathrm{cm}^{-1}$. Uptake of $\mathrm{C}=\mathrm{O}$ group with a sharp peak at $\lambda 1632.88 \mathrm{~cm}^{-1}$, while at $\lambda 1175.01 \mathrm{~cm}^{-1} ; 1084.37 \mathrm{~cm}^{-1}$ and $1031.70 \mathrm{~cm}^{-1}$ indicates the absorption peak of C-O group. The FTIR spectrum of the leather with the addition of $\mathrm{Ag}$ nanoparticles prepared by reducing the betel leaf shows a shift in wavenumber in the $-\mathrm{OH}$ group, $\mathrm{C}-\mathrm{H}$ group, $\mathrm{C}=\mathrm{O}$ and $\mathrm{C}-\mathrm{O}$ groups with wave numbers $3272.65 \mathrm{~cm}^{-1}, 2923.86 \mathrm{~cm}^{-1}, 1632.22 \mathrm{~cm}^{-1}$, $1083.68 \mathrm{~cm}^{-1}$, and $1031.07 \mathrm{~cm}^{-1}$ respectively. In addition to the shift in wavenumber, it also indicates a change in the amount of absorbance.

Modified leather with silver nanoparticles shows a decrease in absorbance especially in the absorption of $-\mathrm{OH}$ groups and $-\mathrm{C}=\mathrm{O}$ groups. This shows that the modification process with silver nanoparticles causes the $-\mathrm{OH}$ group and the $-\mathrm{C}=\mathrm{O}$ group to interact with silver nanoparticles. Consequently, free $-\mathrm{OH}$ uptake and $-\mathrm{C}=\mathrm{O}$ are free to decrease. 
RASĀYAN J. Chem.

Vol. 13 | No. 1 |628 - 635| January - March | 2020

Thus, it could be concluded that the process of modification with silver nanoparticles on suede leather was successfully carried out. However, qualitatively the addition of silver nanoparticles does not change the type of functional group from the leather sample. This is by previous researches, that the addition of $\mathrm{Ag}$ nanoparticles does not change functional groups of textiles sample. ${ }^{21}$

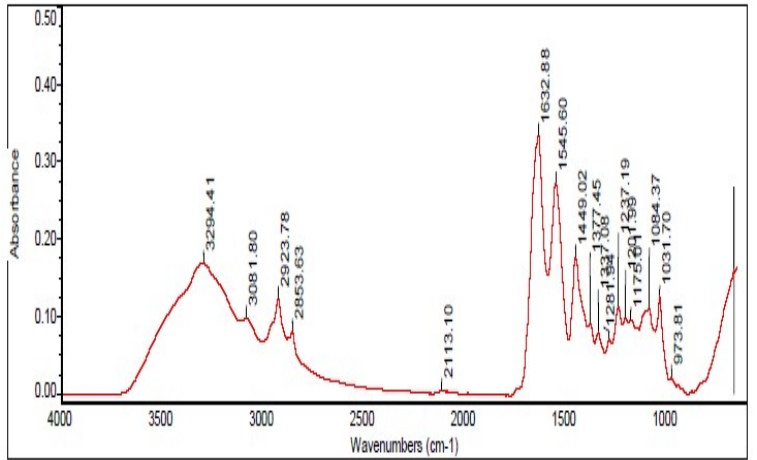

(a)

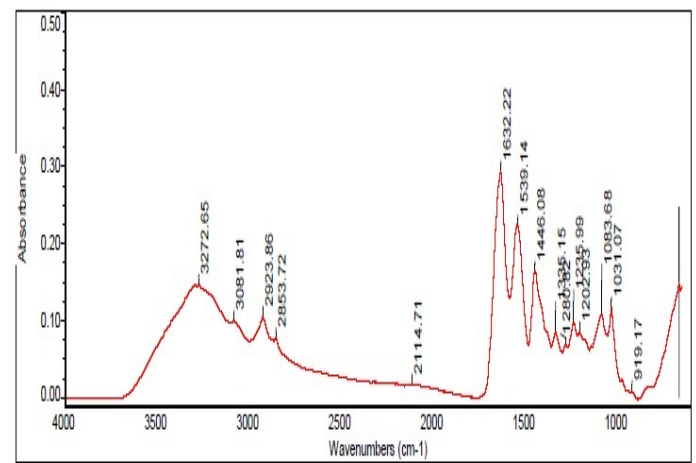

(b)

Fig.-3: The FTIR of (a) Leather and (b) Leather + Silver Nanoparticles

\section{The Morphological Observation of Leather}

SEM observation was intended to see the morphology of silver nanoparticles on the skin using extract reduced from the plant (betel leaf). The results of observations of SEM on grain surfaces with a magnification of 2000x, 5000x, control leather (untreated), and modified leather with silver nanoparticles using reductant betel leaves can be seen in Fig.-4. Fig.-4(a) shows the grain surface of leather (without treatment) with sheet-like shapes.

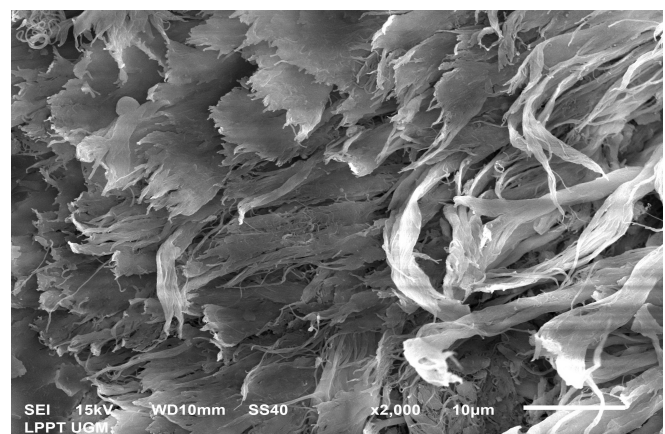

2000x

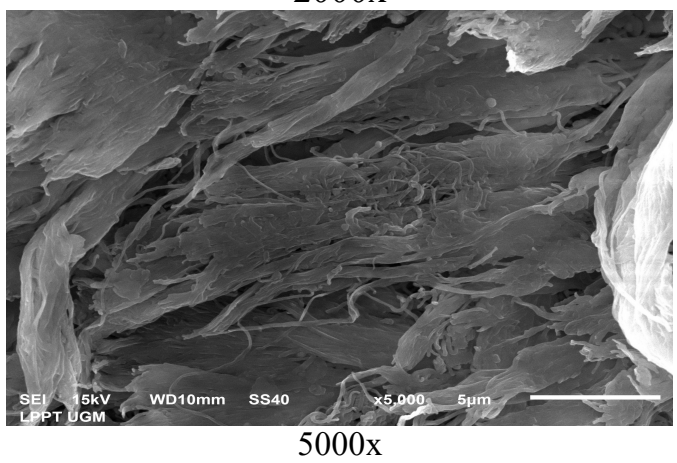

(a)

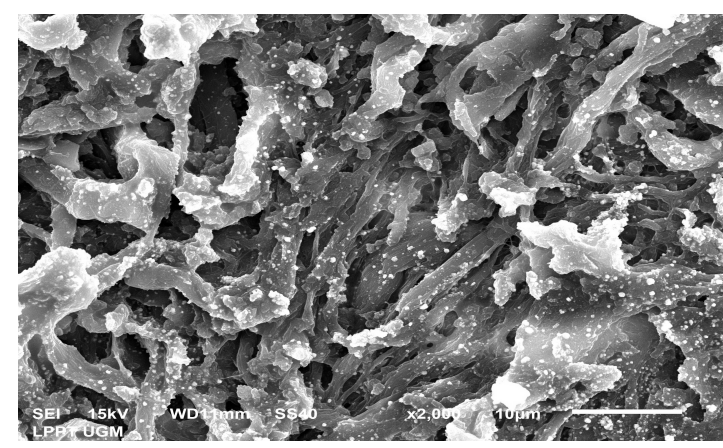

$2000 x$

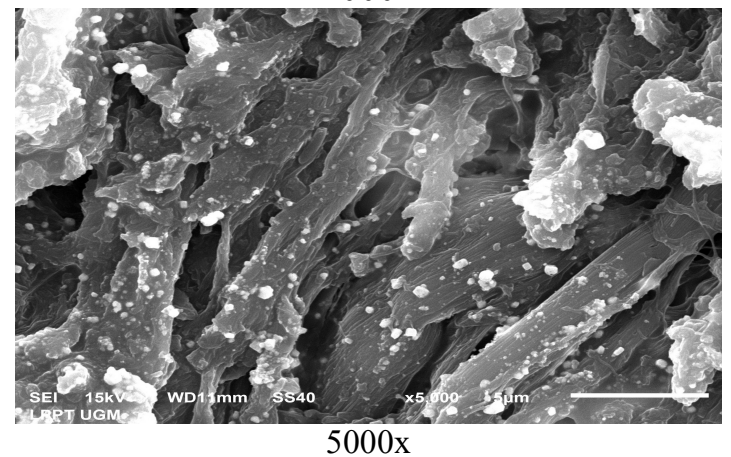

(b)

Fig.-4: The SEM Micrograph of (a) Leather and (b) Leather + Silver Nanoparticles with a Magnification of 2000x and $5000 \mathrm{x}$

The sample is a thin, bright, transparent film that was obtained on the leather substrate. The shape of the silver nanoparticles is spherical with white color spread throughout the leather tissue. This is consistent 
RASĀYAN J. Chem.

Vol. 13 | No. 1 |628 - 635| January - March | 2020

with the results of previous researches that $\mathrm{Ag}$ nanoparticles produced by using plant waste material showed spherical shapes. ${ }^{16}$ Other than that, this result is in line with previous research, namely the deposit of silver nanoparticles on cellulose from rice washing water. ${ }^{22}$

Interaction between suede leather and silver nanoparticle alleged to be chemical adsorption, i.e. via chemical bonding (covalent bond) among $-\mathrm{NH},-\mathrm{COOH}$, $-\mathrm{NHCOO}$ - and Ag. ${ }^{23}$ Although in this research, PVA has been used as a stabilizer for the size of silver nanoparticles produced, however, the size of nanoparticles deposited on the surface of suede leather is not uniform. To increase the size uniformity of nanoparticles that cover the surface of the suede leather can be done by adding surfactants such as the PEG compound. The addition of PEG6000 as a surfactant in the synthesis of zink oxide nanoparticles can effect the size and nature of the nanoparticles produced. ${ }^{24}$ The success of depositing silver nanoparticles on the surface of suede leather is demonstrated by the results of observations with the SEM tool. Therefore the antibacterial activity of suede leather can be caused by the addition of silver nanoparticles. As revealed in previous studies, that silver nanoparticles exhibit antibacterial activity against odors and infections caused by bacteria ${ }^{25}$.

\section{CONCLUSION}

Betel leaf extract was successfully used in the synthesis of colloid of Ag nanoparticles with precursors of silver nitrate solution as showed by the existence of absorption bands at $259 \mathrm{~nm}$ and $456 \mathrm{~nm}$ from the Ultra Violet - Visible spectrum of colloidal Ag nanoparticles. The FTIR spectrum showed that silver nanoparticles were successfully deposited in suede leather with a decrease in the absorption intensity of free $-\mathrm{OH}$ and $-\mathrm{C}=\mathrm{O}$ free from the leather after being modified with silver nanoparticles. SEM photos revealed that the silver nanoparticles were spherical, white in color, and spread throughout the suede leather tissue. The three samples, namely silver nanoparticles, suede leather, and suede leather with the addition of silver nanoparticles had significantly different ability levels to inhibit growth against $S$. aureus and $E$. coli bacteria. The incubation time also significantly affected the inhibition zone of leather samples against the growth of Staphylococcus aureus bacteria. SEM photos show that silver nanoparticles were successfully deposited in suede leather.

\section{ACKNOWLEDGMENT}

I would like to thank the Ministry of Education and Culture of the Republic of Indonesia and also Center for Leather, Rubber, and Plastics, Ministry of Industry of the Republic of Indonesia for financial support.

\section{REFERENCES}

1. M. Abdullah \& Khairurijal, Karakterisasi Nanomaterial Teori, Penerapan dan Pengolahan Data, CV, Rezeki Putera Bandung, Bandung, (2010).

2. V. Vadlapudi, M. Behara and M. N. Devamma, Rasayan Journal of Chemistry, 7, 3 (2014).

3. M. K. Kayguzuz, N. Lkhagvajan, I. Yasa, \& E. Celik, Romania Biotechnological Letters, 21, 5(2016).

4. A. Haryono and S.B. Harmami, Jurnal Kimia Indonesia, 5, 1(2010).

5. E. Rohaeti and A. Rakhmawati, Oriental Journal of Chemistry, 33, 6(2017), DOI: $10.13005 / \mathrm{ojc} / 330625$

6. N. L. Lkhagvajav, M. Koizhaiganova, I. Yasa, E. Chelik and O. Sari, Brazil Journal Microbiology, 46, 1(2015).

7. I. R. Bunghez, M. E. B. Patrascu, N. Badea, S. M. Doncea, A. Popescu and R. M. Ion, Journal of Optoelectronics And Advanced Materials, 11, 4(2012).

8. S. S. Shankar, A. Rai, A. Ahmad and M. Sastry, Journal of Colloid and Interface Science, 275, 2(2004).

9. R. K. Devi, H. N. K. Bhanisana, W. Srma, Radhapiyari and C. H. Brajakishor, International Journal Pharmaceutical Science Review Research, 26, 1(2014).

10. E. Rohaeti, K. S. Budiasih, A. Rakhmawati , E. Nuraini and C. Kusumastuti, Rasayan Journal of Chemistry, 12, 3(2019), DOI:10.31788/RJC.2019.1235179

11. A. Michalak, Polis Journal of Environmental Study, 15, 4(2006).

12. S. Tripathi, Journal of Pharmacognosy and Phytochemistry, 3, 4(2014).

13. N. Karikalan, Rasayan Journal of Chemistry, 11, 4(2018), DOI: 10.31788/RJC.2018.1143068 
RASĀYAN J. Chem.

Vol. 13 | No. 1 |628 - 635| January - March | 2020

14. A. Lagashetty, Bulletin of Advanced Scientific Research, 1, 5(2015), Retrieved from http://asdpub.com/index.php/basr/article/view/252

15. P. S. Praba, J. Jeyasundari, and Y. B. A. Jacob, European Chemistry Bulletin, 3, 10(2014), DOI: 10.17628/ECB.2014.3.1014

16. G. Reddy and A. Thakur, Rasayan Journal of Chemistry, 10(3), 695 (2017), DOI: 10.7324/RJC.2017.1031702

17. L. M. Carillo-Lopez, H. A. Zavaleta-Mancera, A. Vilihis-Netor, R. M. Soto - Hernandez, J. AneusAlatorre, L. I. Trejo-Tellez and F. Gomez-Merino, Journal of Nanomaterials, (2014), DOI: $10.1155 / 2014 / 951746$

18. M. Zakir, Maming, E. Lembang and M. S. Lembang, The International Conference on Advanced Material and Practical Nanotechnology, Jakarta, 2014.

19. A. Haryono, D. Sondari, S. B. Harmami and M. Randy, Jurnal Riset Industri, 2, 3(2008).

20. V. T. Sonja, Lamona, S. Bardin, Jurnal Sains dan Kesehatan, 1, 9(2018).

21. E. Rohaeti and A. Rakhmawati, Chiang Mai Journal of Science, 45, 7(2018).

22. E. Rohaeti, E. Widjajanti LFX and A. Rakhmawati, Jurnal Ilmiah Kimia Molekul, 11, 1(2016), DOI:10.20884/1.jm.2016.11.1.190

23. T. Maneerung, S. Tokura and R. Rujiravanit, Carbohydrate Polymers, 72, 1(2008).

24. A. Kiruthiga1, R. Kannan and T. Krishnakumar, Rasayan Journal of Chemistry, 11, 1(2018), DOI: 10.7324/RJC.2018.1111935

25. P. Velmurugan, S. Lee and M. Cho, Applied of Microbiology \& Biotechnology, 98, 1(2014), DOI: 10.1007/s00253-014-5945-7

[RJC-5516/2019] 